\title{
CHARACTER OF DUTCH LABOUR MARKET IN CONTEXT OF EU $27^{1}$
}

\section{Renata Fajová}

\section{Key words:}

Unemployment, unemployment rate, part-time job, GDP, regression analysis

\section{Klíčová slova:}

nezaměstnanost, míra nezaměstnanosti, práce na částečný úvazek, HDP, regresní analýza

\begin{abstract}
The article shows the situation of unemployment in EU mainly the situation of unemployment in the most affected countries. The Netherlands belongs to the countries with the lowest unemployment rate. The author describes distinctiveness of Dutch labour market and also tries to find the size of influence of GDP to unemployment.
\end{abstract}

\begin{abstract}
Abstrakt
článek poukazuje na problematiku nezaměstnanosti v Evropské unii, obzvlášt' pak v těch zemích, kterých se to týká nejvíc. Nizozemsko patří mezi země s nejnižší mírou nezaměstnanosti. Autor charakterizuje specifika nizozemského trhu práce a v rámci článku je odhadována velikost vlivu HDP na nezaměstnanost.

\section{Introduction}

The Netherlands belongs to the countries which have strong basics for successful keeping of unemployment rate on the lowest level in the EU. All countries were affected by the economic crisis. The impact on individual countries was different. Worldwide there was a downturn in GDP and also to a decrease in employment. The companies have a problem with sales and people who are of productive age are currently out of job. It is necessary to find the way how to reduce the unemployment rate, especially groups with problems to gain a job in a short time.
\end{abstract}

The introductory part of the article is devoted to a short description of recent situation of unemployment in the EU. Most countries overcame the economic crisis and now they are coping with the consequences of the crisis. In some countries there is still a problem in the form of unemployment. Instead of decreasing of unemployment, the problem still persists.

Given the positive phenomenon on the Dutch labour market, another part of the paper is devoted to analyzing the relationship of GDP and unemployment. It was particularly interested in risk groups in the labour market, especially women and young people. The most vulnerable group in the labour market is usually young people under 25 years and unemployment is higher in women than in men group.

\section{Situation of unemployment in recent months in EU}

The unemployment rate differs in individual economies. The Eurostat figures (table 1) showed overall unemployment in the 27-member European Union, which was 9.6 percent. Latvia, Lithuania, Spain are the economies with the highest unemployment rate.

\footnotetext{
${ }^{1}$ The article was created under the project SGS 23/2010.
} 
Latvia belongs to the countries with the highest unemployment rate. In December 2008 the unemployment rate was $7 \%$. By December 2009, the figure had risen to $22.8 \%$. The number of unemployed has more than tripled since the beginning of the crisis, giving Latvia the highest rate of unemployment growth in the EU. The active employment policy is weak. Also expenditures on ALMPs at $0.1 \%$ are low compared to $0.5 \%$ at the EU average $e^{2}$. In 2009 retail sales in Latvia dropped by almost $30 \%$ - another European record. In the second half of 2008 and the first half of 2009, rating quickly sank at international agencies, and the forecasts of other financial and economic development of the country were worse. Considering the utter lack of liquidity, the government was obliged to seek assistance abroad with the European Commission and the International Monetary Fund. The condition for an approval and the gradual utilization of financial support was developing a plan to stabilize the Latvian economy, so that the funds actually will be a benefit for the economy and led to a gradual healing. The government has taken useful fiscal measures, e.g. reduce investment in expensive modern technology on the ground level, comparable with the degree of development of Latvia (Slovakia, Mexico, etc.); the disbursement of pensions, benefits and health were revised; reduction of unemployment benefits (limited to 6 months); etc. Currently, there is a revival of the economy, which is also reflected by the development of unemployment. The largest fall of unemployment was observed in Latvia $(20.1 \%$ in 4Q/09 to $17.3 \%$ in $4 \mathrm{Q} / 2010)$.

Lithuania has around 3.5 million inhabitants. Almost every third young Lithuanian is a client of labour office. More than $37 \%$ of economically active young people are without work. The unemployment rate moves around $18 \%$. Lithuania belongs to agrarian states and almost $22 \%$ of people have not jobs in agriculture. Last year the number of unemployed persons increased by $4.5 \%$ (74 thousand). The particularly serious problem is the number of job seekers, which is around 324 thousand in the country with 3.5 million inhabitants. Legislators see the main problem in illegal work. Illegal work wins on all of fronts, not only in the category of illegal foreign workers, but also of domestic employees. In short, a law should be passed which will stop any illegal work, and it will probably be difficult. Undeclared work is rooted and mutually beneficial.

Spain solves significant problems: it has a lot of unemployed and too old population. According to Spanish statisticians, it is the highest unemployment rate since 1998, over $20 \%$. Regarding the absolute number of unemployed, it is the most in the history -4.4 million unemployed in the country with 46 million people. The unemployment rate has risen sharply during the economic crisis and now it is the highest in the EU. The labour market misses flexibility. The Spanish economy has been suffering the problem of the rigid labour market for a long time. It is hard to lay off someone who has a contract for an indefinite period. Therefore, the Spanish employers are afraid of recruiting new people. It is one of the reasons, why the number of unemployed is so high. Young people are the most affected group. The youth unemployment rate (under 25 years) was $43.5 \%$ in February 2011.

In contrast, there are countries where the unemployment rate does not exceed 5\%, e.g. the Netherlands, Austria and Luxembourg (table 1).

\footnotetext{
${ }^{2}$ ec.europa.eu/economy_financeldb_indicators/labref/pdf/latvia_en.pdf
} 
Table 1: Harmonised unemployment rate (\%)

\begin{tabular}{|c|c|c|c|c|c|c|c|c|c|c|c|}
\hline geoltime & 2010M03 & 2010M04 & 2010M05 & 2010M06 & 2010M07 & 2010M08 & 2010M09 & 2010M10 & 2010M11 & 2010M12 & 2011M01 \\
\hline European Union (27) & 9,6 & 9,6 & 9,6 & 9,6 & 9,6 & 9,6 & 9,6 & 9,6 & 9,6 & 9,6 & 9,5 \\
\hline Belgium & 8,4 & 8,4 & 8,4 & 8,4 & 8,5 & 8,4 & 8,3 & 8,3 & 8,2 & 8,1 & 8 \\
\hline Bulgaria & 9,7 & 9,9 & 10 & 10 & 10 & 10 & 10,1 & 10 & 10,1 & 10,1 & 10,2 \\
\hline Czech Republic & 7,8 & 7,5 & 7,3 & 7,2 & 7,1 & 7,1 & 7,1 & 7,2 & 7,3 & 7,7 & 7,5 \\
\hline Denmark & 7,3 & 7,5 & 7,4 & 7,5 & 7,3 & 7,4 & 7,6 & 7,7 & 7,8 & 7,9 & 8,2 \\
\hline Germany & 7,1 & 7 & 6,9 & 6,8 & 6,7 & 6,7 & 6,6 & 6,6 & 6,6 & 6,6 & 6,5 \\
\hline Estonia & 18,9 & 18 & 18 & 18 & 15,9 & 15,9 & 15,9 & 14,3 & 14,3 & 14,3 & \\
\hline Ireland & 13 & 13,3 & 13,6 & 13,6 & 13,6 & 13,7 & 13,9 & 13,9 & 13,8 & 13,7 & 13,5 \\
\hline Greece & 11 & 12,2 & 12,2 & 12,2 & 12,9 & 12,9 & 12,9 & : & $:$ & : & : \\
\hline Spain & 19,6 & 19,8 & 20 & 20,2 & 20,3 & 20,5 & 20,6 & 20,6 & 20,5 & 20,4 & 20,4 \\
\hline France & 9,8 & 9,8 & 9,8 & 9,8 & 9,7 & 9,7 & 9,7 & 9,7 & 9,7 & 9,7 & 9,6 \\
\hline Italy & 8,5 & 8,5 & 8,6 & 8,4 & 8,4 & 8,4 & 8,5 & 8,7 & 8,6 & 8,6 & 8,6 \\
\hline Cyprus & 6,5 & 6,7 & 6,9 & 7 & 6,9 & 7 & 7 & 7,1 & 7,2 & 7,3 & 7,4 \\
\hline Latvia & 20 & 19,4 & 19,4 & 19,4 & 18,3 & 18,3 & 18,3 & & & : & \\
\hline Lithuania & 17,3 & 18,2 & 18,2 & 18,2 & 18,3 & 18,3 & 18,3 & 17,4 & 17,4 & 17,4 & \\
\hline Luxembourg & 4,6 & 4,6 & 4,6 & 4,7 & 4,7 & 4,7 & 4,7 & 4,7 & 4,8 & 4,8 & 4,7 \\
\hline Hungary & 11,1 & 11,2 & 11,1 & 11,2 & 11,2 & 11,1 & 11,2 & 11,4 & 11,5 & 11,8 & 12,6 \\
\hline Malta & 7 & 7 & 6,7 & 6,6 & 6,6 & 6,4 & 6,4 & 6,4 & 6,2 & 6,2 & 6,1 \\
\hline Netherlands & 4,5 & 4,5 & 4,5 & 4,5 & 4,6 & 4,5 & 4,4 & 4,4 & 4,4 & 4,3 & 4,3 \\
\hline Austria & 4,6 & 4,6 & 4,5 & 4,4 & 4,4 & 4,4 & 4,3 & 4,2 & 4,2 & 4,2 & 4,3 \\
\hline Poland & 9,8 & 9,6 & 9,6 & 9,6 & 9,6 & 9,6 & 9,6 & 9,7 & 9,7 & 9,7 & 9,7 \\
\hline Portugal & 10,7 & 10,9 & 11,1 & 11,1 & 11,1 & 11,1 & 11,2 & 11,2 & 11,2 & 11,2 & 11,2 \\
\hline Romania & 7,3 & 7,1 & 7,1 & 7,1 & 7,3 & 7,3 & 7,3 & : & $:$ & : & : \\
\hline Slovenia & 6,9 & 7,2 & 7,3 & 7,4 & 7,2 & 7,3 & 7,3 & 7,5 & 7,5 & 7,7 & 7,8 \\
\hline Slovakia & 14,6 & 14,5 & 14,5 & 14,5 & 14,4 & 14,4 & 14,5 & 14,5 & 14,5 & 14,5 & 14,5 \\
\hline Finland & 8,6 & 8,6 & 8,5 & 8,4 & 8,4 & 8,3 & 8,2 & 8,1 & 8,1 & 8 & 8 \\
\hline Sweden & 8,5 & 9 & 8,7 & 8,1 & 8,4 & 8,2 & 8,2 & 8 & 7,8 & 7,8 & 7,8 \\
\hline United Kingdom & 7,8 & 7,8 & 7,7 & 7,8 & 7,7 & 7,7 & 7,8 & 7,8 & 7,8 & 7,9 & \\
\hline
\end{tabular}

$:=$ not available

Source: Eurostat - http://epp.eurostat.ec.europa.eu/portal/page/portal/statistics/search_database 


\section{Relationship of GDP and unemployment in the Netherlands}

According to theory, there is a relation between GDP growth and decreasing unemployment rate. Does the overall unemployment rate respond to the development of GDP? Does this sensitivity differ for age or sex group? The analysis is done on the basis of comparison of annual changes of unemployment and comparison of GDP since 2004.

Chart 1: Annual changes of unemployment rate and real GDP (\%)

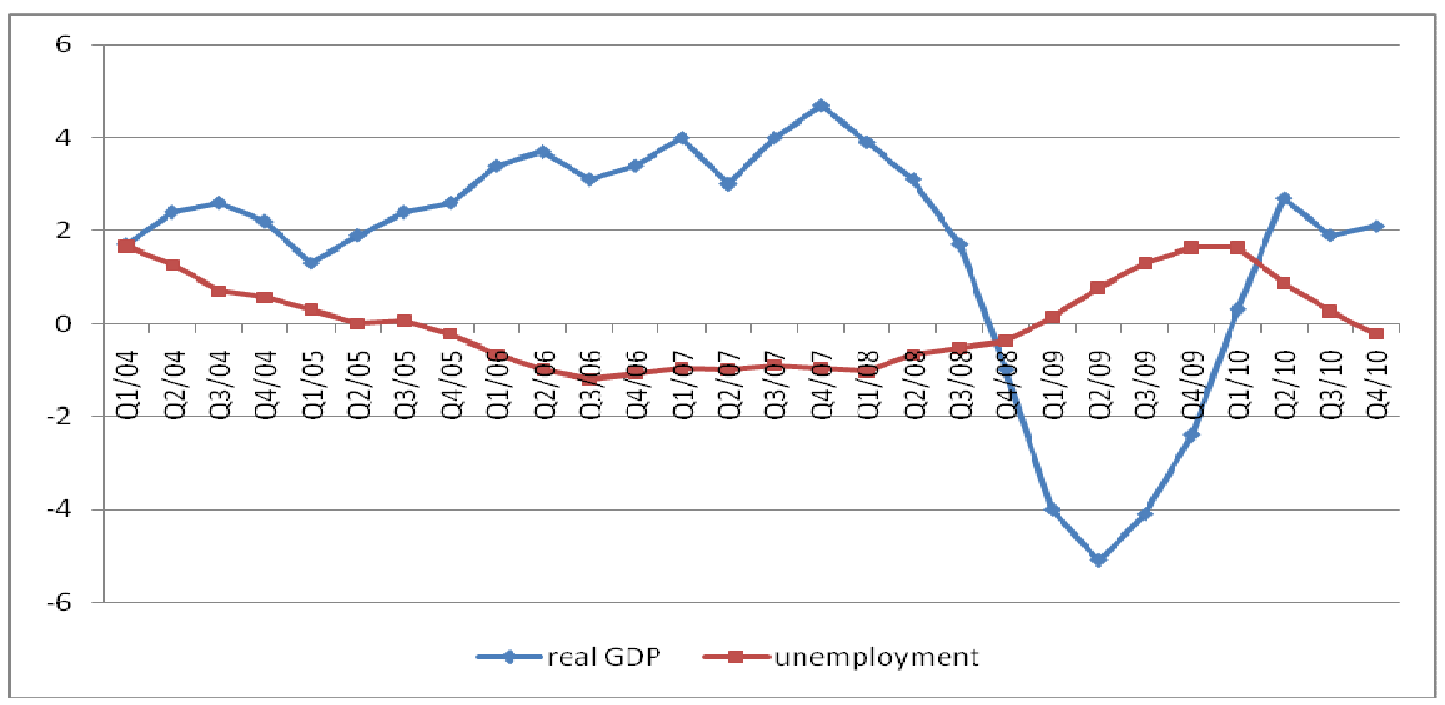

Source: data from OECD and CBS Statline

Chart 1 shows the development of annual changes of GDP and unemployment. The greatest decline in GDP was observed in Q2/09 - 5.1\% compared with last year. Consequently, the percentage of unemployed persons was increased by $1.6 \%$ in $4 \mathrm{Q} / 09$ compared with $4 \mathrm{Q} / 08$.

Scatter diagram confirms the empirical relationship between annual change in unemployment rate and annual percentage change in real GDP. The estimate of linear model is in the form:

$\Delta$ unemployment rate $_{\mathrm{t}}=-0,29 * \Delta$ real $\mathrm{HDP}_{\mathrm{t}-2}+0,36+\varepsilon$

Chart 2: The relationship between real GDP and unemployment rate

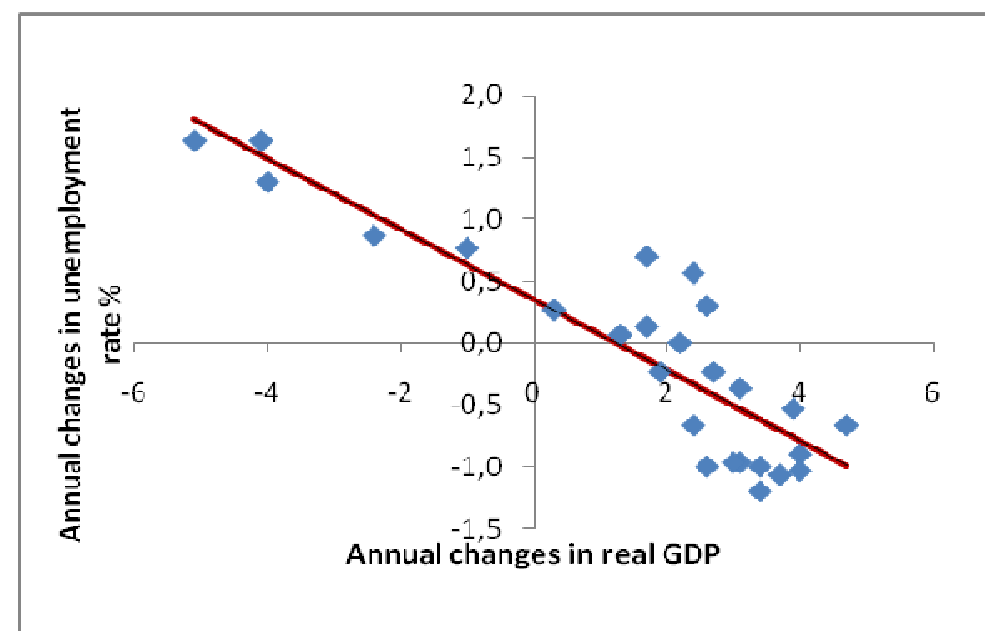

unemployment rate $\mathrm{ccc}=-0.15$.
The increase in GDP growth rate by $1 \%$, unemployment rate is falling by $0.29 \%$.

The development of employment on GDP responds with a lag. The variability of annual changes of GDP and the variability of annual changes of employment, shifted by 2 quarters, are explained by more than $78 \%$. Cross-correlation coefficient $\left(\mathrm{GDP}_{\mathrm{t}-2}\right)$ shows a low dependence of real GDP and the 


\subsection{The structure of unemployment by age}

Every economy has had a problem with youth unemployment rate (for less than 25 years). In the EU27, the unemployment was $20.4 \%$ in February 2011. Traditionally, the Dutch youth unemployment rate is the lowest $(7.4 \%)$. Through regression analysis it is possible to show the influence of GDP on youth unemployment rate.

Chart 3: Annual changes in real GDP and unemployment rate by age

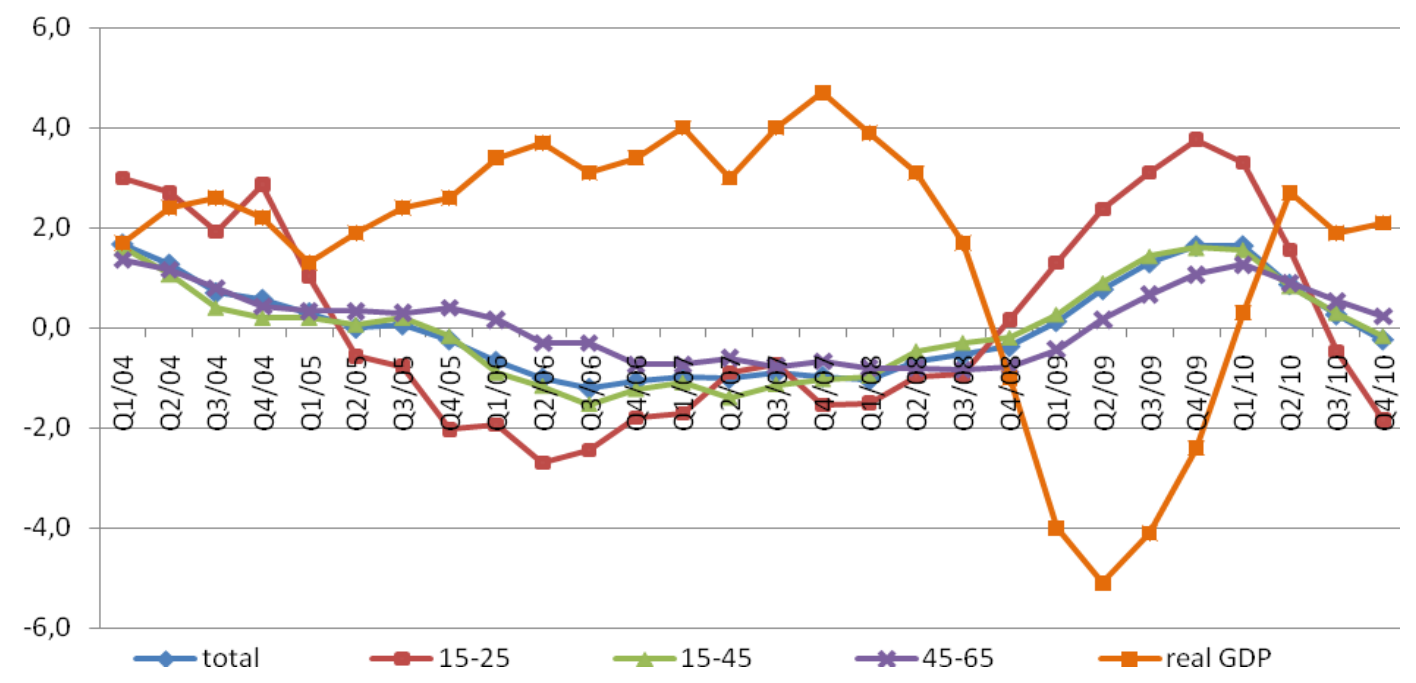

Source: data from OECD and CBS Statline

Chart 3 captures a process of annual changes in real GDP and unemployment rate by age. At first glance it is obvious that the highest sensitivity to change in GDP is in youth unemployment rate. Compared with $4 \mathrm{Q} / 08$, the unemployment rate in age $15-25$ increased by $3.8 \%$ in $\mathrm{Q} 4 / 09$.

Chart 4: The relationship between GDP and unemployment rate by age 15-25

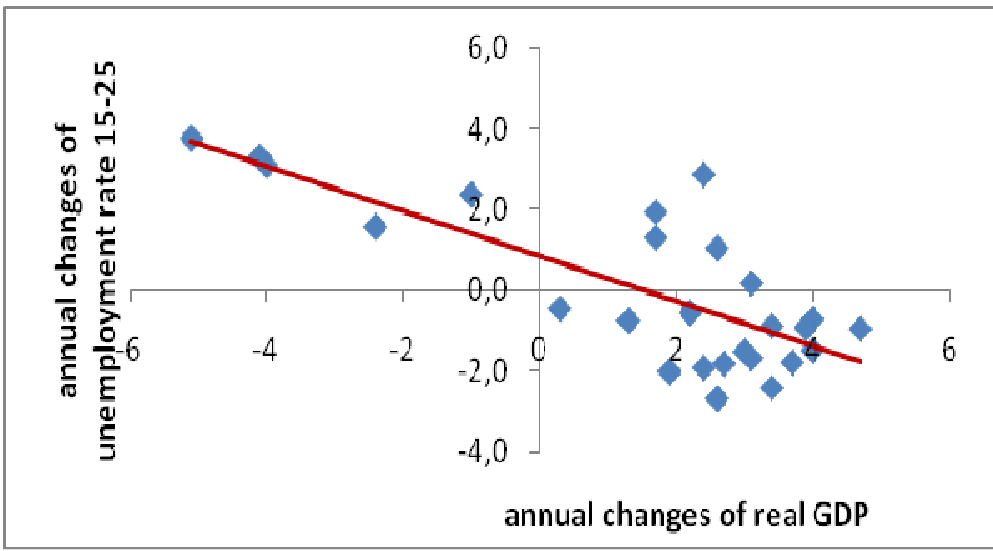

The estimate of linear model is in the form:

$\Delta$ unemployment rate $15-25_{\mathrm{t}}=-$ $0,55 * \Delta$ real $\mathrm{HDP}_{\mathrm{t}-2}+0,84+\varepsilon$

The increase in GDP growth rate by $1 \%$, unemployment rate $15-25$ is falling by $0.55 \%$.

In this case, the variability of annual changes of GDP and the variability of annual changes of employment $15-25$, shifted by 2 quarters, is explained by more than $68 \%$. Cross-correlation coefficient is -0.32 . 


\subsection{The structure of unemployment by sex}

Chart 5 captures annual changes in real GDP and the unemployment rate by sex. In times of recession, the unemployment rate increased more quickly in men than in women group.

Chart 5: Annual changes in real GDP and annual changes in unemployment rate by sex

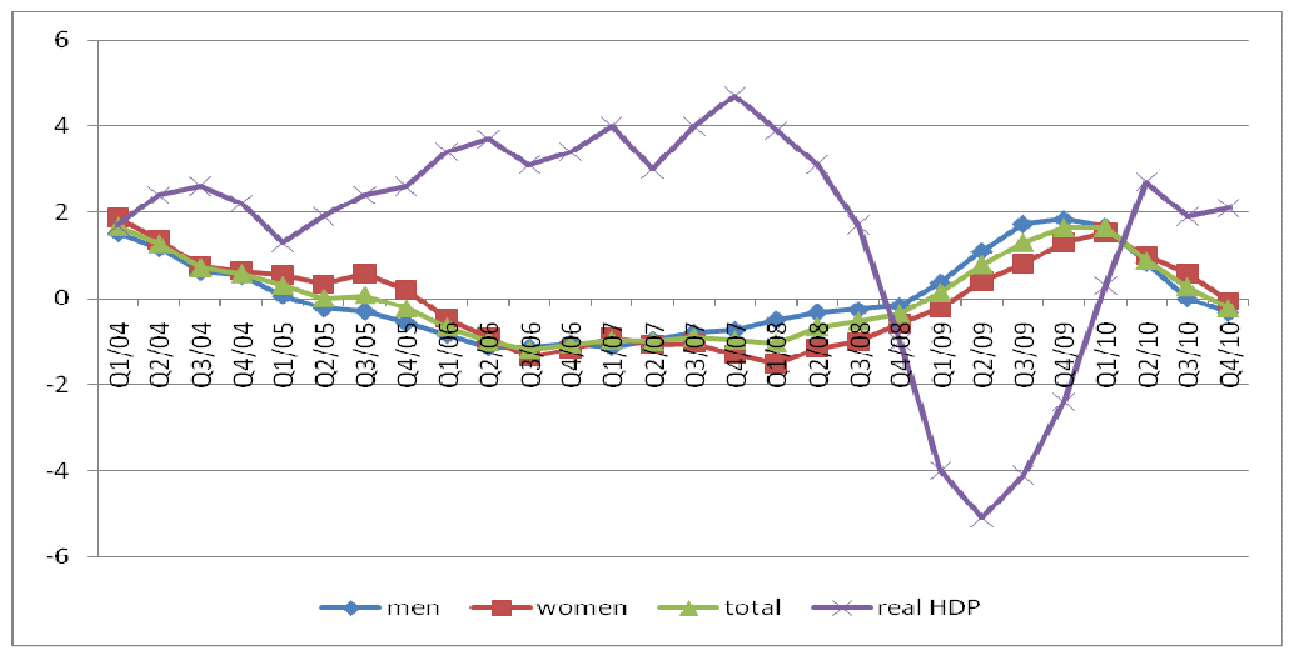

Source: data from OECD and CBS Statline

For both, men and women, the relationship between the annual change in specific rates of unemployment and annual GDP growth is statistically significant. The estimates of linear regression models:

$\Delta$ unemployment rate $(\text { women })_{\mathrm{t}}=-0.16 * \Delta$ real $\mathrm{HDP}_{\mathrm{t}-2}+0.74+\varepsilon$

$\Delta$ unemployment rate $(\text { men })_{\mathrm{t}}=-0.29 * \Delta$ real $\mathrm{HDP}_{\mathrm{t}-2}+0,9+\varepsilon$

Chart 5: The relationship between GDP and unemployment rate by sex

There are differences between the sexes in the tendency of the regression lines, and thus in the sensitivity of the response of unemployment to GDP, and in the tightness of this relationship. The variability of GDP growth explains nearly $75 \%$ of the variability of unemployment among men and almost $66 \%$ of the variability of unemployment among women. Crosscorrelation coefficient for

unemployment rate of men is -0.27 , for unemployment rate of women is 0.1 .

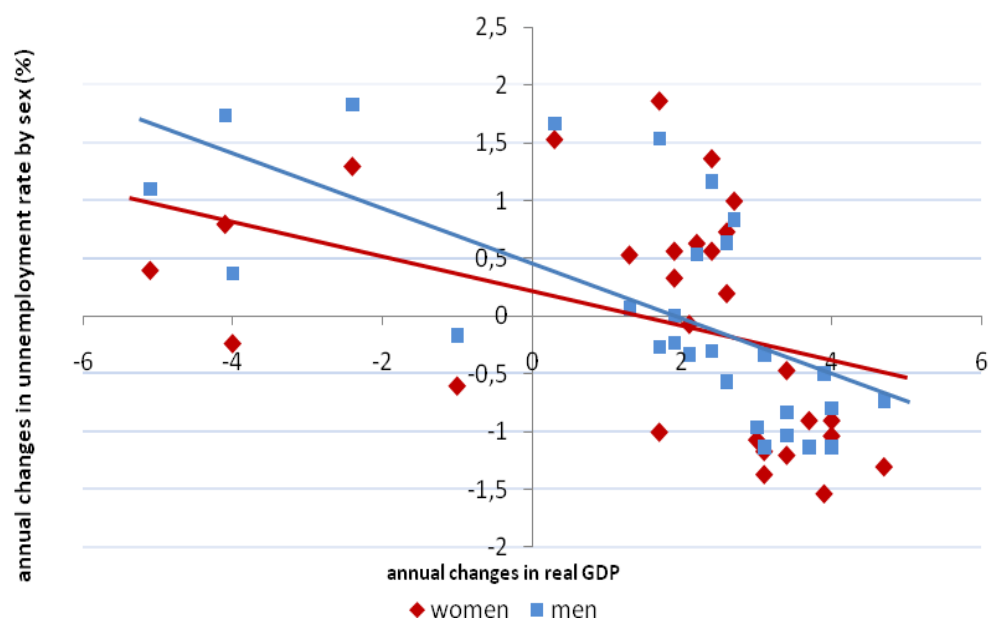




\section{Distinctiveness of Dutch labour market}

Among the typical characteristics of the labour market in the Netherlands belongs mainly:

Part time employment is common and widespread in the Netherlands very much than in the other EU countries. Almost $39 \%$ of economically active people has part-time job. In the rest of EU the average number is $17 \%$. Female part-time work remains much more popular in the Netherlands than in any other country.

Women belong to a vulnerable group in the labour market in every economy. The proportion of women having part-time job is $70 \%$ (17\% men). An interesting fact is, that the highest increase was noted in women aged 35-45. A slight increase was also in women aged 45-65.

Table 2: Number of employed labour force aged 15-64

\begin{tabular}{|c|c|c|c|c|c|c|c|c|c|}
\hline \multirow{3}{*}{$\begin{array}{c}\text { Sex/ } \\
\text { Periods }\end{array}$} & \multicolumn{3}{|c|}{ 12-19 hours a week } & \multicolumn{3}{|c|}{ 20-34 hours a week } & \multicolumn{3}{|c|}{$>=35$ hours a week } \\
\hline & Total & Men & Women & Total & Men & Women & Total & Men & Women \\
\hline & $\times 1000$ & $\times 1000$ & $\times 1000$ & $\begin{array}{r}\times 1000 \\
\end{array}$ & $\begin{array}{r}\times 1000 \\
\end{array}$ & $\times 1000$ & $\begin{array}{r}\times 1000 \\
\end{array}$ & $\times 1000$ & $\begin{array}{r}\times 1000 \\
\end{array}$ \\
\hline 2005 & 702 & 121 & 581 & 1908 & 475 & 1433 & 4363 & 3474 & 890 \\
\hline 2006 & 712 & 121 & 590 & 1964 & 487 & 1477 & 4422 & 3492 & 930 \\
\hline 2007 & 738 & 135 & 604 & 2054 & 497 & 1557 & 4517 & 3554 & 963 \\
\hline 2008 & 736 & 143 & 593 & 2174 & 517 & 1657 & 4591 & 3606 & 985 \\
\hline 2009 & 721 & 137 & 584 & 2244 & 536 & 1708 & 4504 & 3527 & 977 \\
\hline 2010 & 713 & 138 & 575 & 2281 & 553 & 1729 & 4397 & 3429 & 968 \\
\hline
\end{tabular}

Source: statline.cbs.nl

In table 2, it is possible to see the number of women working less than 35 hours a week. Particularly the increasing number of women working 20-34 hours a week is the highest number of economically active women. Some believe that the growth of women's participation in the labour market was because of decreasing of wages which is a key factor of successful output of the entire Dutch labour market. But the key to success here was the development and support of part-time job. Although in many countries a part-time job is still associated with the idea of temporary employment, with relatively poor working conditions and low wages. In the Netherlands, most of those who have part-time jobs signed a proper long-term contract and has the same work under the same conditions as those who work full time. Although there exist some differences, but they are not significant.

The government also laid the certain legal bases for the relatively secure situation of employees working part-time. Moreover, the government as one of the largest employers is in itself an example and allows its employees part-time work. The reason why so many people are employed part-time is mainly the fact that these contracts are treated in a legally sufficient way, and also that they are highly popular by both the employers and employees.

During the 1980s and 1990s, part-time work was considered a way to decrease the high female unemployment rate. However, the attitude of policymakers about part-time work has changed. Now, a part-time job is often considered a trap in which the full potential of women remains unexploited. Part-time working women are paid less and have fewer opportunities for promotions. Therefore, increasing working hours would be beneficial for their labour market position. Stimulating female labour supply is also considered to be a potential source to increase economic growth and deal with the costs of an ageing society. In 2008, the "Committee on Labour Force Participation" installed by the Dutch government 
argued that the high number of part-time workers is one of the main weaknesses of the Dutch labour market. The committee advised the government to stimulate participation rates and increase working hours, particularly among women. To stimulate non-working women to enter the labour market and working women to increase their working hours, income tax rules should be changed to make work pay more. ${ }^{3}$

In 2001 the Netherlands had a tax reform. But without strong effect on increasing a number of female work hours. Average weekly hours of work increased by 0.4 ( $2 \%$ of average working hours in the population). Tax incentives more contributed to increased participation than working hours.

Part-time work is like "habit" in the Netherlands. Main reason why there is so high proportion of female in part-time work is taking care about young children. Constantly there is a strong opinion that if a woman works full time with young children, the family suffers. Women are also satisfied with part-time working.

On the one hand, part-time work is a very effective tool for decreasing unemployment in female population. There is a possibility how to combine family life and work. On the other hand, $70 \%$ of women have part-time jobs. It is a really high percentage of female population.

\section{Conclusion}

Problems with unemployment are a common consequence of economic crisis. Every government of countries made a plan how to keep the unemployment rate down. The countries with mismanagement did not keep unemployment in the low level. Latvia, Lithuania and Spain are countries where unemployment is a huge economic problem.

The Dutch economy has consistently low unemployment rate in the EU. If we focus on the relationship of unemployment and GDP, we find that the sharpest decrease of GDP was in the second quarter of 2009. GDP decreased by $5.1 \%$ y-o-y. The decrease in GDP evoked a growth in unemployment. The number of unemployed climbed to 470,000. It is evidently cyclical than structural unemployment.

In this article, the goal was to explore the dependence of two vulnerable groups in the labour market on GDP - women and young people. As regards the sensitivity of unemployment in the 15-25 age group, it has shown that the reduced GDP by $1 \%$ causes increasing of unemployment by $0.55 \%$. It shows the increased sensitivity of this group to the economic development. It is possible to say that it confirms the belief that young people are vulnerable in the Dutch labour market. The problem is especially school leavers and young people with low qualifications. Employers also prefer people with experience.

The regression analysis of relationship between GDP and unemployment rate by sex showed greater sensitivity of unemployment rates for men than for women to GDP. The same shows cross-correlation coefficient (unemployment rate of men to real $\mathrm{GDP}_{\mathrm{t}-2}$ is -0.27 and unemployment rate of women to real $\mathrm{GDP}_{\mathrm{t}-2}$ is almost insignificant). Women constitute a group in the labour market which uses part-time work. Almost $70 \%$ of women have a parttime job. The Netherlands has efficacious way how to reduce unemployment in the risk group, i. e. women. On the other hand, a part-time job is often considered a weakness because full potential of women remains unexploited.

\footnotetext{
${ }^{3}$ http://www.voxeu.org/index.php?q=node/3946
} 


\section{Literature:}

[1] BLANPAIN, R. The global labour market: from globalization to flexicurity. 1. publ. Netherlands: Kluwer Law International, 2008, 378 p. ISBN: 9789041127228.

[2] Business info: www.businessinfo.cz

[3] EDERVEEN, S., THISSEN, L. Can labour market institutions explain unemployment rates in new EU member states? CPB Document. 1. Publ. The Haque: CPB Netherlands Bureau for Economic Policy Analysis, 2004, 66 p. ISBN 90-5833-174-X.

[4] Eurostat: http://epp.eurostat.ec.europa.eu

[5] FELSTEAD, A., JEWSON, N. Global trends in flexible labour. 1. publ. London: Macmillan press Ltd., 1999, 213 p. ISBN: 0-333-72998-6.

[6] KNOTEK, EDWARD S. How Useful Is Okun's Law. Economic Review, Federal Reserve Bank of Kansas City, 2007, pages 73-103. http://www.kansascityfed.org/Publicat/ECONREV/PDF/4q07Knotek.pdf

[7] OECD: www.oecd.org

[8] PELLEŠOVÁ, P. Hospodářská politika A. 1. vyd. Karviná: SU OPF, 2006, 141 s. ISBN 80-7248-370-6.

[9] Specific problems of the labour market in Latvia and its regions: www.lm.gov.lv/upload/darba_tirgus/darba_tirgus/.../specific_problems.pdf

[10] The Dutch statistical office: http://statline.cbs.nl/statweb/

[11] VOX - research - based policy analysis and commentary from leading economists www.voxeu.org

Classification JEL: E24

\section{Ing. Renata Fajová}

Department of economy

School of Business Administration in Karvina

Silesian University in Opava

Univerzitní nám. 1934/3, 73340 Karviná

Czech Republic

fajova@opf.slu.cz 